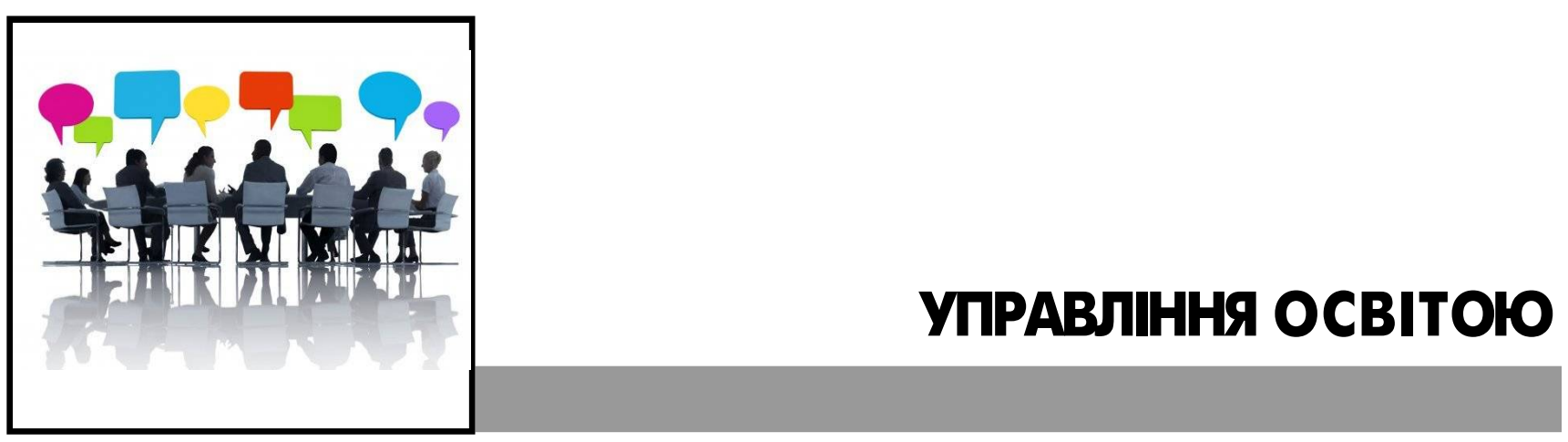

УДК: 373.2:351.851

ЮЛІЯ СОЛОВЕЙ, аспірант кафедри дошкільної освіти, Черкаський національнии університет імені Богдана Хмельнииького, Україна ORCID 0000-0003-4778-7640 solovey_yula@ukr.net

\title{
ЗАРУБІЖНИЙ ДОСВІД УПРАВЛІННЯ СИСТЕМОЮ ДОШКІЛЬНОЇ ОСВІТИ
}

\author{
YULIIA SOLOVEI, PhD student of Preschool \\ Education Department, Cherkasy Bohdan \\ Khmelnitsky National University, Ukraine
}

\section{FOREIGN EXPERIENCE OF PRE-SCHOOL EDUCATION MANAGEMENT}

У статті обгрунтовано доцільність вивчення досвіду країн зарубіжжя для вирішення сучасних проблем управління дошкільною освітою в Україні. Проаналізовано досвід управління та контролю системи дошкільної освіти в Польщі, Молдові, Німеччині, Франції та Кореї. 3'ясовано, що механізми управління та контролю системи дошкільної освіти цих країн мають свої особливості та історичне підгрунтя. Встановлено, що спільним в управлінні діяльністю закладів дошкільної освіти у країнах зарубіжжя є ієрархічна система управління та професійна підготовка інспекторів щодо перевірки роботи таких закладів. Наголошено, що система дошкільної освіти в кожній 3 країн є розвиненою, але продовжує вдосконалюватися в контексті сучасних вимог до навчання і виховання дітей. Виокремлено ідеї, які можна впроваджувати в управлінні системи дошкільної освіти в Україні.

Ключові слова: управління, дошкільна освіта, досвід країн зару-

() Ю. Соловей біжжя, освітній простір, інтеграція, заклад дошкільної освіти, директор.

Summary. The article substantiates the expediency of studying the experience of foreign countries forsolution of modern problems of pre-school management in Ukraine. The experience of management and control of the preschooleducation system in Poland, Moldova, Germany, France and Korea is analyzed. It is found that the mechanisms of management and control of the pre-school education system in these countries have their own peculiarities and historical background. It is established that a hierarchical system of management and professional training of inspectors in checking the activity of such institutions is common in managing the activities of pre-school education institutions in foreign countries. It is emphasized that the system of pre-school education in each of the countries is developed, but continues to be improved in the context of current requirements for education and upbringing of children. The ideas that can be implemented in the management of the pre-school education system in Ukraine are highlighted.

Key words: management, preschool education, experience of foreign countries, educational space, integration, pre-school education institution, director.

Мета: проаналізувати систему управління дошкільною освітою в зарубіжних країнах.

Постановка проблеми в загальному вигляді. Нині сучасне суспільство потребує досконалої системи управління освітою, що зумовлено проблемою якості освітньої системи України. Особливо важливі питання якості освіти пов'язані із загальними орієнтирами процесу модернізації системи освіти на всіх рівнях. Вагому роль у системі безперервної освіти України, так як i в багатьох інших країнах світу, відіграє дошкільна освіта, яка $є$ первинною ланкою в досягненні триєдиної мети - освітньої, розвивальної та виховної. Сьогодні управління дошкільною освітою залишається одним із пріоритетних напрямів державної освітньої політики в 
нашій державі.

Зміни, що відбуваються в дошкільній освіті, знаходять своє відображення та регулюються відповідними законодавчими документами - законами України "Про освіту", "Про дошкільну освіту", "Про охорону дитинства", Національною стратегією розвитку освіти України до 2021 р., Базовим компонентом дошкільної освіти в Україні (Козак \& Швидка, 2017, с. 199).

Процеси інтеграції та входження української системи освіти в міжнародний освітній простір формують перед сучасною теорією і практикою управління не лише завдання 3 вивчення далекосяжного праці вітчизняних науковців (Н. Карпенко, Н. Мельник, М. Олійник та ін.). Загальні питання дошкільного виховання відображено в наукових роботах багатьох дослідників (А.Барбарига, Т. Вернигора, Н. Веракса, Н. Винокурова, В. Лапчинська, В. Меньшиков, Л. Сундукова, T. Тарасова та інші). Проблема змісту дошкільної освіти знайшла втілення у працях зарубіжних науковців (Т. Блекстоун, К. Бол, Т.Брюс, Дж. Дарлінг, Я. Квон, Л.Кеннінгтон, Б. Мун та інші) (Гарник, 2015, с. 21).

Виклад основного матеріалу дослідження. Проблема управління дошкільною освітою є актуальною, оскільки необхідність своєчас-

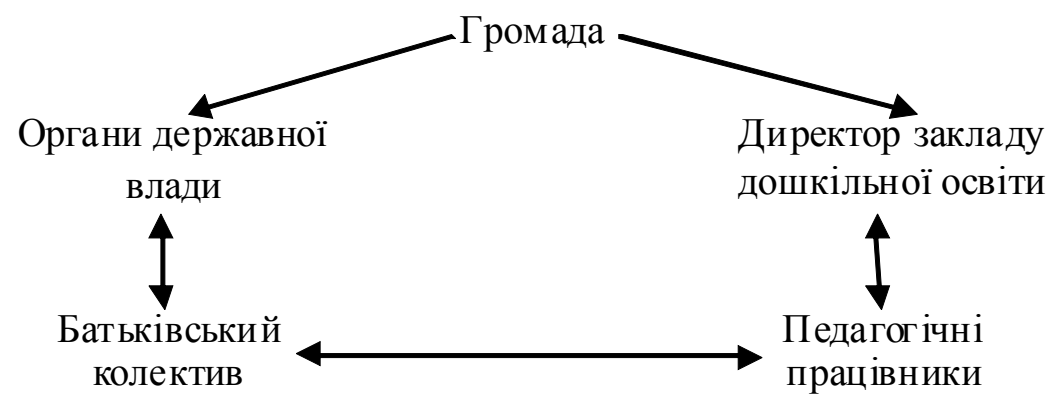

\section{Рис. 1. Взаємозв'язок системи забезпечення я кісной освітн вої діяльності закладу доикільної освіми}

досвіду, але й вимагають з'ясування сутності окремих педагогічних явищ та зіставлення різних аспектів педагогічної освіти країн-партнерів 3 сучасною системою управління дошкільною освітою України (Мельник, 2017, с. 36).

Великий педагогічний потенціал міститься в зарубіжних системах освіти, які мають свою історію та традиції. Їх вивчення може сприяти вирішенню проблем,пов'язаних 3 управлінням у галузі дошкільної освіти в Україні (Козак, 2018, с. 237).

Тому вважаємо за необхідне зосередити увагу на вивченні питання управління дошкільною освітою в зарубіжних країнах.

Аналіз досліджень і публікацій. Питання дослідження зарубіжного досвіду дошкільної освіти постає об'єктом студіювання багатьох дослідників (В. Зебзеєва, С. Дудко, Л.Литвин, Т. Поніманська та ін.). Вивченню проблеми професійної підготовки фахівців дошкільної освіти у країнах зарубіжжя присвячені впровадження кращого досвіду зарубіжних країн у систему управління освітою України.

Аналізуючи наукові праці зарубіжних колег (Х. Гренбська, Е. Браньська, М. Келар, Т. Левовіцкі, Х. Рачек, Р. Шульц, Й. Шчепаньські), передусім звертаємо увагу на особливості управління дошкільною освітою в Польщі (Антонюк, с. 2). Ocновна мета полягає в підтримці та стимулюванні розвитку дитини, урахуванні потреб та можливостей особистості (Polish.., 2009, c. 14).

Загальні завдання дошкільного виховання (від трьох років) описані в національній навчальній програмі та в регламенті Міністерства національної освіти (підтримка та сприяння інтелектуальному, емоційному, соціальному, творчому та естетичному розвитку дітей, вивчення іноземної мови) (Schreyer \& Oberhuemer, 2017, c. 2).

Дошкільна освіта в Польщі не $\epsilon$ обов'язковою, проте діти 6-го року життя мають відвідувати або дитячі садки (przedszkola), або передшкільні класи, що приєднані до початкової школи (oddzialyprzedszkolne). Міністерством національної освіти і спорту введено обов'язковий 0 клас, починаючи $з$ 2004/2005 навчального року. Управлінням державних закладів дошкільної освіти займаються органи місцевого самоврядування - комуни (Polish.., 2008, c. 14).

Основну роль в ініціації та здійсненні контролю за освітньою політикою відіграє міністр національних справ. Міністр національної освіти зобов'язаний консультуватися 3 педагогічними спілками щодо рішень, які приймаються в галузі освіти, а в певних випадках отримати їх схвалення. Міністерство національної освіти відповідає за майже всю систему освіти,за винятком вищої освіти, яка перебуває під наглядом міністра науки (Polish.., 2008, c. 16).

Управління дошкільною освітою відбувається децентралізовано, тобто відповідальність за управління закладами дошкільної освіти передана місцевим органам (комунам) (kuratoroswiaty, REA). Міністр національної освіти координує та проваджує державну освіту, частково контролює роботу керівників освітніх установ і співпрацюе 3 ними (Polish.., 2008, c. 16). Органи освіти вживають заходів лише в разі 
недотримання законодавчих вимог (Schreyer \& Oberhuemer, 2017, c. 8).

Зазначимо, що заклади дошкільної освіти повинні мати офіційний мандат на забезпечення освіти, виховання та догляд дитини, а також мусять бути зареєстровані в муніципалітеті, який безпосередньо контролює їхню діяльність. Окрім того, закладу дошкільної освіти для провадження своєї діяльності необхідна позитивна оцінка від органів 3 питань запобігання пожежам та охорони здоров'я (Polish.., 2008, c. 3).

Муніципалітети відповідають за підбір адміністрації, організацію роботи закладів дошкільної освіти та забезпечення місць для 5-7річних дітей.

Ключовими документами для зовнішнього та внутрішнього оцінювання дитячих садків та дошкільних закладів $є$ Указ міністра національної освіти від 2017 року щодо вимог до шкіл та інших навчальних закладів, а також указ про педагогічний нагляд (Polish, 2008, c. 9). Педагогічний нагляд, зокрема, полягає в оцінюванні стану й умов дидактичної, виховної та опікунської діяльності навчального закладу і педагогів; аналізі та оцінюванні результатів дидактичної, виховної та опікунської діяльності, іншої статутної діяльності навчального закладу; наданні допомоги навчальному закладу, а також педагогам у виконанні ними дидактичних, виховних і опікунських завдань; спонуканні педагогів до педагогічних, методичних і організаційних інновацій.

Директор навчального закладу протягом семи днів від дати одержання рекомендацій, зауваг і висновків може заявити про застереження щодо них до органу педагогічного нагляду (ОПН) (Шиян, 2016, c. 36).

Керівники та працівники дитячих садків відповідають за внутрішні оцінки. Результати зовнішніх та внутрішніх оцінок $€$ основою для моніторингу якості на ранній стадії виховання дітей та ініціювання дискусій щодо покращення якості освіти (Polish, 2008, c. 9).

Система підготовки майбутніх вихователів закладів дошкільної освіти постійно змінюється та вдосконалюється. Зараз досить популярними закладами освіти є: трирічні навчальні коледжі для викладачів, вищі навчальні школи (педагогічні академії) та педагогічні факультети університетів (Polish.., 2008, c. 16).

Варто зазначити, що досвід Польщі досить перспективний для використання в Україні. Маємо на увазі саме досвід розвитку адміністративного й освітнього самоврядування місцевих одиниць, які перебувають у різних умовах і мають постійно шукати власні шляхи розвитку базової освіти, опираючись на власний інтелект та ресурси (Шиян, 2016, с. 13).

Для розширення кругозору знань системи управління дошкільною освітою країн зарубіжжя розглянемо ієрархію управління закладами дошкільної освіти Молдови. Головною метою тут бачиться вдосконалення процесу виховання дитини та мотивація бажання вчитися без зусиль, що сприятиме забезпеченню особистого успіху дошкільника. Виховання дітей до 3-х років, зазвичай, проводиться в сім'ї, яка за законом отримує державну підтримку. На прохання батьків, за рішенням та за підтримки місцевої громадськості, органи влади або роботодавці можуть сприяти отриманню дошкільної освіти дітьми до 3-х років (ясла). Держава гарантує матеріальну та фінансову підтримку виховання дітей у яслах та дитсадках. Дошкільне виховання дітей віком від 3-х до 6-ти (7) років організовується в межах дитячих садків (Gutan \& Fuior, 2014, c. 70-76).

Законодавчими повноваженнями управління та нагляду у сфері дошкільної освіти наділені парламент Молдови та уряд Молдови, місцеві державні адміністрації та місцеві ради (місцева державна адміністрація контролює дитячі заклади, які розташовані в селах (комуни) та містах (муніципалітети); також під владою державної адміністрації знаходяться дитячі заклади, що розташовані в районах).

Органи місцевого самоврядування (вищого та нижчого рівнів) мають певний ступінь самостійності та влади у прийнятті та ухваленні рішень. Цей підхід до управління дозволяє уряду на національному рівні здійснювати контроль за основними параметрами системи освіти. Узагалі, прихильники децентралізації Молдови припускають, що покладання обов'язків на місцеві органи влади при- веде до кращої ефективності освіти, аніж тоді, коли всі рішення прийматимуться централізовано (Moldova, 2018, c.14-15).

Загалом центральний уряд встановлює політику, норми та правила фінансування закладу дошкільної освіти. Обов'язками надання офіційного мандату директорам шкіл та дошкільних закладів, управління педагогами та допоміжним персоналом і керівництвом освітнім процесом у закладі та виконанням бюджету займаються органи місцевого самоврядування нижчого рівня. У свою чергу, органи місцевого самоврядування вищого рівня мають різні обов'язки, які пов'язані із загальними питаннями освіти, включаючи забезпечення дотримання нормативних вимог, прийняття рішень про створення та закриття закладів, прийняття на роботу та звільнення керівництва (Moldova, 2018, c.18).

Таким чином, управління дошкільною освітою в Молдові $\epsilon$ спільною цілісною системною компетенцією між національним урядом першого та другого рівнів i відповідно органами місцевого самоврядування. Кожна структурна одиниця відповідає за підвищення якості дошкільної освіти.

Більшість освітніх установ у Німеччині є державними, проте в країні переважають приватні дошкільні установи. Управління освітою знаходиться в розпорядженні земельних урядів (у країні їх 16) та $\epsilon$ децентралізованим, що не виключає загального керівництва з боку центрального уряду: Міністерство освіти розробляє концепцію освітньої політики, виділяє кошти на розширення установ освіти. Згідно 3 Конституцією у Німеччині держава контролює систему освіти у країні, але разом $з$ тим у кожному земельному уряді існує міністерство, що керує всіма освітянськими питаннями. Державними органами керівництва $є$ Міністерство науки та освіти, Комітет з наукових досліджень та питань освіти, Наукова рада, Рада з питань освіти.

У Німеччині здійснюється моніторинг (моніторинг - процедура систематичного збирання даних про важливі аспекти на загальнодержавному, регіональному чи локальному рівнях (А. Тайджиман, Т. Несвілл Послтвейт) розвитку дитини, що спрямований на досягнення 
трьох цілей: 1) підвищення продуктивності персоналу; 2) виявлення потреб у навчанні персоналу; 3) сприянні розвитку дитини. Уряд Німеччини прагне покращити ефективність роботи персоналу та підвищити поінформованість громадськості $з$ питання якості освіти (Germany, 2016, c. 5-22).

За розробку та проведення системи моніторингу відповідають місцеві органи влади, тому країна має широке поле для моніторингу якості персоналу за допомогою інспекцій. Німецькі інспекції здійснюють опитування, що проводяться інспекторами; розробляють рейтингові шкали та обгрунтовують результати самооцінок.

Для того, щоб інспектор міг здійснювати перевірку закладу, він обов'язково має пройти навчання для зовнішніх оцінювачів. Після завершення такого навчання особа отримує сертифікат якості (BETAGutesiegel). Сертифікат якості - це результат проходження особою, яка претендує на звання "інспектор" 10-денного курсу, що забезпечує теоретичну та практичну підготовку (Lergetporer,Werner \& Woessmann, 2017, c. 4-5).

Відтак внутрішні перевірки передбачають: самооцінювання, огляди та тести для персоналу, а зовнішні - опитування та експертні огляди. Країна використовує моніторинг для систематичного збирання інформації про якість роботи персоналу в закладах дошкільної освіти (Germany, 2016, c. 5-22).

Німецький уряд указує на ряд причин, які зумовлюють проведення моніторингу якості дошкільної освіти: підзвітність, інформація про діяльність закладу, інформування громадськості, підвищення рівня якості обслуговування, продуктивності персоналу, визначення потреби навчання в персоналі, покращення розвитку дитини та окреслення навчальних потреб дітей. Варто зазначити, що для уряду країни $\epsilon$ важливим інформування громадськості про якість провадження діяльності того чи іншого закладу дошкільної освіти (Germany, 2016, c. 5-22).

Отже, система управління та контролю за дошкільною освітою Німеччини має багатофункціональне значення. Тут існує єдиний орган управління, проте забезпеченням якості освітніх послуг, пла- нуванням та провадженням освітньої діяльності займаються всі земельні уряди, які, у свою чергу, співпрацюють 3 метою досягнення єдиної освітньої мети.

Франція - унітарна держава 3 трьома рівнями децентралізованого уряду, у кожному з яких $є$ посадові особи, котрі виконують певні фінансові та юридичні обов'язки (https://www.oecd.org/francel 34400146.pdf., c. 8). У країні обов'язки з питань освіти та догляду за дітьми розподілені між органами Міністерства соціальних питань та охорони здоров'я дітей (Ministere des Affaires sociales et de la Sante) (догляд за дітьми до досягнення 3річного віку), Міністерством Національної освіти (Ministere de l'Education nationale) дітей дошкільного віку (від 2-3-х до 6-ти років).

Ліцензування послуг закладів дошкільної освіти здійснює Агентство захисту "Дитина та мати" (Protection Maternelle et Infantile), a національний уряд разом 3 місцевою владою проводить акредитацію та ліцензування дошкільних закладів. Обслуговування і якість персоналу відстежуються у французьких установах по догляду за дітьми дошкільного віку. Також існує система моніторингу якості дошкільної освіти, що передбачає перевірки та самооцінку якості послуг у догляді за дітьми.

Інспекції Франції вагому увагу приділяють якості роботи персоналу, використанню відповідних матеріалів, що сприяють усебічному розвитку дитини, управлінню часом та плануванню, командній роботі з колегами та можливостям професійного розвитку (France, 2016, c. 2).

Неабияку роль у перевірці закладу дошкільної освіти відіграє співвідношення "персонал-дитина", "здоров'я та правила гігієни", "техніка безпеки, контролю умов праці та управління людськими й фінансовими ресурсами". Існують три основні інструменти, що використовуються для моніторингу: 1) прямі оцінки (тести для дітей); 2) розповідні оцінки (розповіді та портфоліо); 3 ) інструменти спостереження (рейтингові шкали та контрольні списки) (France, 2016, c. 18).

Французький уряд вважає, що проведення моніторингу якості закладів та персоналу дасть змогу прослідкувати результати підвищення якості надання освітніх послуг, проте результати моніторингу, зазвичай, не розповсюджуються для широкої громадськості (France, 2016 , c. 7).

Отож питання управління та контролю дошкільної освіти Франції є досить актуальним. Великого значення надається перевірці внутрішньої роботи закладу, загальному розвитку дітей. Вагому роль у перевірці відіграє командна робота закладу, ефективне управління діяльністю закладу з боку його директора.

У контексті нашого дослідження зацікавлення викликає система управління дошкільною освітою країн Азії, зокрема Кореї, оскільки в цій країні прослідковується впровадження ідей, які були б доцільними для застосування в системі управління дошкільною освітою України.

Корейська дошкільна освіта має дворівневу систему: дитячі садки (діти віком 3-5-ти років), котрі знаходяться під контролем Міністерства освіти, науки та технологій, та заклади по догляду за дітьми (діти віком від народження до 5-ти років), що підконтрольні Міністерству охорони здоров'я та добробуту.

Для роботи 3 дитиною дошкільного віку вихователь має отримати Свідоцтво вихователя дитячого садка, яке надається Міністром освіти, науки та технологій на основі Закону "Про освіту дітей" та посвідчення "Виховательпо догляду за дітьми", що надається Міністром охорони здоров'я.

У країні створений Центр розвитку дитячої політики (грудень 2005 р.), що функціонує як інститут досліджень, спрямований на проведення комплексних спостережень 3 питань догляду за дітьми. Центр працює за фінансової підтримки Міністерства освіти, розвитку науки та технологій і Міністерства гендерної рівності. Результати досліджень завжди публічно оприлюднюються.

У Кореї докладають багато зусиль для досягнення якісного вдосконалення та стандартизації догляду за дітьми, а саме зусилля щодо: якісного догляду за дітьми шляхом запровадження системи оцінювання дитячих закладів та дитячих садків; зусилля щодо створення i впровадження системи оцінювання та сертифікації дитячих закладів; удосконалення системи інспекту- 
вання дитячих закладів (Policy, 2008, с. 64-79).

Якість послуг контролюється в Кореї кожних три роки, а якість персоналу - щорічно. Такий контроль проводиться для інформування громадськості про рівень якості обслуговування та визначення потреби розвитку персоналу і з метою підзвітності. Перевірка якості послуг у країні також відбувається 3 метою діагностики задоволення батьків наданими послугами.

У цій країні існує два види інспекцій: інспекція якості обслуговування та інспекція якості персоналу. Зокрема, інспекції якості обслуговування зосереджують свою увагу на дотриманні правил внутрішнього розпорядку;виконанні навчальних програм; використанні відповідних навчальних матеріалів; умовах праці, плануванні роботи та управлінні фінансовими і людськими ресурсами. Інспекції якості персоналу перевіряють якість освітнього процесу, знання предметів, можливості професійного розвитку педагогів та розвиток дитини.

Досить популярним методом перевірки в Кореї є самооцінка якості послуг та персоналу. Самооцінки якості послуг мають всебічну спрямованість: загальну якість освітнього процесу; якість персоналу; дотримання правил; якість ігрового та освітнього середовища; співпраця між персоналом, керівництвом та батьками; доступність і використання матеріалів; виконання навчальних програм; умови праці.

Самооцінка якості персоналу зосереджується на застосуванні матеріалів; виконанні навчальної програми; роботі в команді; спілкуванні з батьками; навичках управління і лідерства.

При перевірці використовують різноманітний діагностичний інструментарій - спостереження, шкали оцінок, контрольні списки, інтерв'ю, опитування, результати самооцінок та аналіз документації. Експертні огляди та опитування батьків практикуються у дитячих садках для оцінки ефективності роботи персоналу. Експертна оцінка показує можливості директора та педагогічного персоналу управляти часом, навички планування та роботу в команді (Korea, 2016, с. 3).

Таким чином, система контро- лю та управління дошкільною освітою Кореї є досить різноманітною, адже тут діють декілька інспекцій, що використовують широкий спектр методів роботи із закладами дошкільної освіти. Велика увага зосереджується на співпраці педагогічного персоналу з його директором та працівниками інших освітніх установ. Проте менше уваги приділено моніторингу всебічного розвитку дитини.

Висновки та перспективи подальших досліджень. У процесі проведеного дослідження підтверджено, що освіта є особливою функцією суспільства та держави. Невід'ємною складовою будь-якої освітньої системи, у даному випадку - системи дошкільної освіти, є управління та контроль.

У процесі наукового пошуку виявлено, що в системах управління дошкільною освітою зарубіжних країн є схожі риси, хоча кожна країна має свої специфічні особливості управління та контролю, власний перспективний досвід. Запозичення зарубіжного досвіду управління дошкільною освітою може сприяти поліпшенню системи управління та контролю дошкільною освітою в Україні. Відтак корисним стало б: 1) забезпечення Міністерства освіти і науки України, а саме директорату дошкільної та шкільної освіти головного управління загальної середньої та дошкільної освіти фахівцями в галузі дошкільної освіти (стаж педагогічної роботи не менше 5-ти років); 2) забезпечення районних, міських відділів освіти фахівцями в галузі дошкільної освіти; 3) запровадження проведення закладами дошкільної освіти всеукраїнських та міжнародних конференцій з теми "Управління дошкільною освітою: досвід та перспективи"; 4) запровадження підготовчих курсів для інспекторів, які беруть участь у проведенні атестації чи інституційного аудиту закладу дошкільної освіти; 5) запровадити курси для директорів закладів дошкільної освіти з теми "Мистецтво роботи в команді: взаємодія педагогічного колективу"; 6) тотальний контроль за працевлаштуванням за фахом випускників закладів вищої освіти; 7) контролююча функція директора закладу дошкільної освіти, що проявляється у професійному відборі кадрів $з$ фаховою дошкільною освітою.
Перспективним напрямом подальших наукових розвідок $\epsilon$ вивчення закордонного досвіду підготовки педагогічних кадрів у галузі дошкільної освіти.

\section{СПИСОК ЛІТЕРАТУРИ}

Антонюк, Ю. Компаративнийаналізсистемиуправліннядошкільниминавчальними закладами в Польщі та Україні. URL : http:// eprints.zu.edu.ua/24264/1/ Антонюк.pdf. (дата звернення: 5.11.2019).

Гарник, I. (2015). Генеза змісту дошкільної освіти у Великій Британії (історичний аспект). Scienceand Educationa NewDimension. PedagogyandPsychology, 61, 21.

Козак, Л. (2017). Сучасна дошкільна освіта: європейський досвід. Освітологічний дискурс, 3, 237. Doi: 10.28925/2312- 5829.2017.3-4.2351

Козак, Л., Швидка, I. (2018). Якість дошкільної освіти на сучасному етапі. Освітологічний дискурс, 3, 199.Doi: 10.28925/2312-5829

Мельник, Н. (2017). Профілі професійної компетентності та професійної підготовки фахівців дошкільної освіти у європейських країнах. Актуальні проблеми педагогіки, психології та професійної освіти, 1,36 .

Мельник, Н. (2011). Розвиток дошкільної освіти у США. (Автореф. дис. ... канд. пед. наук), Київ.

Шиян, Р. (2016). Децентралізація освіти у Польщі: досвід для України, Київ.

Early Childhood Education and Care Policy in France Directorate for Education. OECD.2004. URL : https:/ / w w w. o e c d. or g / f r a n c e / 34400146.pdf.(дата звернення: 9.11.2019).

France. Starting Strong IV Monitoring Quality in Early Childhood Education and Care Country Note OECD. (2016). URL : http://www.oecd.org/education/ school/ECECMN-France.pdf (дата звернення: 9.11.2019).

Germany. Starting Strong IV Monitoring Quality in Early Childhood Education and Care Country Note OECD. (2016). URL: http://www.oecd.org/education/ school/ECECMN-Germany.pdf. (дата звернення: 9.11.2019).

Gutan, V. \& Fuior, E. (2014). Major trends in preschool education funding in the republic of Moldova. 
Journal of Research on Trade, Management and Economic Development, 1, 70-76.

Korea. Starting Strong IV Monitoring Quality in Early Childhood Education and Care Country Note OECD. (2016). URL : http://www.oecd.org/education/ school/ECECMN-Korea.pdf (дата звернення: 8.11.2019).

Lergetporer, P., Werner, K. \& Woessmann L. (2017). Public opinion on education policy in Germany. Germany: IZA - Institute of Labor Economics, 10948, 41.

Moldova preschool and general education: transitioning to a decentralized service delivery model selected. (2018). URL: htt p : // documents.worldbank.org/curated/ en/106571523893165988/pdf/123660REVISED-PUBLIC-P161676-MDDecentralization-Analysis-final-forimagebank-4-2018.pdf(дата звернення: 7.11.2019).

Policy and practice of early childhood education and Careacross countries. Tokyo Japan: The Department for International Research and Cooperation National Institute for Educational Policy Research (NIER). (2009).

Polish eurydiceunit the system of education in Poland Warsaw. Poland, (2008).

Schreyer, I. \& Oberhuemer, P. (2017). Poland - Key Contextual Data. Poland.

\section{REFERENCES}

Antoniuk, Yu. Komparatyvnyi analiz systemy upravlinnia doshkilnymy navchalnymy zakladamy v PolshchitaUkraini. URL : http://eprints.zu.edu.ua/24264/1/ Антонюк.pdf. (data zvernennia:

\subsubsection{9).}

Harnyk, I. (2015). Heneza zmistu doshkilnoi osvity u Velykii Brytanii (istorychnyiaspekt). Science and Education a New Dimension. Pedagogy and Psychology, 61, 21.

Kozak, L. (2017). Cuchasna doshkilna osvita: yevropeiskyi dosvid. Osvitolohichnyi dyskurs, 3 , 237. Doi: $10.28925 / 2312-5829.2017 .3-$ 4.2351

Kozak, L. \& Shvydka, I. (2018). Yakist doshkilnoi osvity na suchasnomu etapi. Osvitolohichnyi dyskurs, 3, 199. Doi: 10.28925/23125829

Melnyk, N. (2017). Profili profesiinoi kompe tentnosti ta profesiinoi pidhotovky fakhivtsiv doshkilnoi osvity u yevropeiskykh krainakh. Aktualni problemy pedahohiky, psykholohii ta profesiinoi osvity, 1, 36.

Melnyk, N. (2011). Rozvytok doshkilnoi osvityu SShA. (Avtoref. dys. ...kand. ped. nauk). Kyiv.

Shyian, R. (2016). Detsentralizatsiia osvity u Polshchi: dosvid dlia Ukrainy. Kyiv.

Early Childhood Education and Care Policy in France Directorate for Education. OECD. (2004). URL : https://www.oecd.org/france/ 34400146.pdf.(data zvernennia: 9.11.2019)

France. Starting Strong IV Monitoring Quality in Early Childhood Education and Care Country Note OECD. (2016). URL : http://www.oecd.org/education/ school/ECECMN-France.pdf (data zvernennia: 9.11.2019).

Germany. Starting Strong IV Monitoring Quality in Early Childhood Education and Care Country Note OECD. (2016). URL : http://www.oecd.org/education/
school/ECECMN-Germany.pdf. (data zvernennia: 9.11.2019).

Gutan, V. \& Fuior, E. (2014). Major trends in preschool education funding in the republic of Moldova. Journal of Research on Trade, Management and Economic Development, 1, 70-76.

Korea. Starting Strong IV Monitoring Quality in Early Childhood Education and Care Country Note OECD. (2016). URL : http://www.oecd.org/education/ school/ECECMN-Korea.pdf (data zvernennia: 8.11.2019).

Lergetporer, P., Werner, K. \& Woessmann, L. (2017). Public opinion on education policy in Germany. Germany: IZA - Institute of Labor Economics, № 10948. 41 p.

Moldova preschool and general education: transitioning to a decentralized service delivery model selected. (2018). URL: htt p : / / documents.worldbank.org/curated/ en/106571523893165988/pdf/123660REVISED-PUBLIC-P161676-MDDecentralization-Analysis-final-fori ma g e ba n k-4-2018.pdf(dat a zvernennia: 7.11.2019).

Policy and practice of early childhood education and Careacross countries. Tokyo Japan: The Department for International Research and Cooperation National Institute for Educational Policy Research (NIER). (2009).

Polish eurydiceunit the system of education in Poland Warsaw. Poland. (2008).

Schreyer, I. \& Oberhuemer, P. (2017). Poland-Key Contextual Data. Poland.

Стаття надійшла 16.11.19p. 